\title{
DiGITÁLIS ÍRÁSTUDÁS
}

\section{IKT MÜHELY, INTERAKTÍV TÁBLA}

\section{Kubinger-PiLlmanN JUdit}

\author{
a Pannon Egyetem Nyelvtudományi és Neveléstudományi Doktori Iskolájának \\ PhD hallgatója \\ judit.pillmann@gmail.com
}

Napjainkban, digitális írástudás nélkül nehezen intézhetjük hivatalos ügyeinket, lassan üzenhetünk ismerőseinknek és sorolhatnánk még azokat a hátrányokat, amelyek akkor érhetnek bennünket, ha nem veszünk tudomást az információs és kommunikációs technika (IKT) térhódításáról. A digitális kompetencia a nyolc EU-s kulcskompetencia egyike, de azon belül is elsődleges, hiszen a mai világban elengedhetetlen a különféle információs technológiák, hálózatok és kommunikációs rendszerek ismerete.

Az IKT eszközök nemcsak a mindennapi életünkben foglalnak el fontos szerepet, hanem az iskolák életében, az oktatási-nevelési folyamatban is. A diákok otthonosan mozognak a digitális eszközök világában. Ezek a fiatalok szinte gond nélkül kezelik a multimédiás eszközöket, de a használat célszerüsége, gyakorlati jelentősége nem mindig tudatosul bennük. A pedagógus felelőssége és feladata abban áll, hogy ezeknek a digitális eszközöknek a használatát ésszerü mederbe terelje és segítséget nyújtson ahhoz, hogy a diákok megértsék, ezen eszközök szerepe miért fontos az információk keresésében, átalakításában, értékelésében a mindennapokban, a tanulás során, a munkában és a szabadidőben. Nem könnyü az a feladat. Ebben a kihívásokkal teli, de izgalmas munkában nagy segítséget jelenthet az a tananyagcsomag, amit az Educatio Társadalmi Szolgáltató Kht. és az Eszterházy Károly Főiskola együttmüködése során megvalósított szakmai múhely hozott létre. A mühelymunka célja az volt, hogy a pedagógusok ötleteket, jól alkalmazható módszereket láthassanak a digitális eszközökkel segített óratervezéshez, óravezetéshez, valamint a diákjaik és saját digitális kompetenciájuk fejlesztéséhez. Mindez azért nagyon fontos, mert a digitális tananyagok, az interaktív táblák, az osztálytermi szavazórendszerek jelentős változást hoztak/hoznak a tanítás-tanulás folyamatába.

Az IKT mühely címet viselő csomag egy DVD-ből és a DVD tartalmi elemeit hagyományos, papíralapú formában megjelenítő könyvből áll. A könyv és a DVD szerkezeti felépítése azonos. Az Educatio Társadalmi Szolgáltató Kht. és az Eszterházy Károly Főiskola közös együttmüködésének bemutatása után, Falus Iván be- 
vezető gondolatai következnek, majd néhány alapvető, digitalizációval kapcsolatos fogalom tisztázása történik meg. A csomag második nagyobb blokkja 14, digitális eszközökkel, főként interaktív táblával segített tanórarészletet tartalmaz. Az IKT műhely elméleti bevezetője olyan fontos fogalmak jelentését rendszerezi, mint a digitális kompetencia, e-learning, digitális pedagógia, instruktív és konstruktivista pedagógia különbségei, projekt alapú tanulás, felfedező tanulás, IKT eszközökkel támogatott tanulás, virtuális közösségek. Az IKT mühely DVD változatában az elméleti bevezető digitalizált formában is megtalálható, így a felhasználó könnyen navigálhat az egyes pontok között.

Az IKT mühely második része kiváló, teljes mértékben gyakorlati segítség a pedagógusoknak. Összesen 14 tanóra követhető végig a DVD-én, s elérhetők a tanórák óravázlatai is (a tanóra célja, szint, az óra menete, a számítógép használatot megelözö munka, munka a számitógéppel, a számitógép használatot követö mun$k a$ ), az órához szükséges hardver és szoftver igények, valamint az órákkal kapcsolatos javaslatok, észrevételek. A javaslatok az IKT mühely szakmai tesztelése során fogalmazódtak meg. Ebben a munkában 5 iskola vett részt ${ }^{1}$. Az egyes óravázlatoknál jelölődik az is, hogy az adott óra melyik iskolában, milyen tantárgyból, hányadik osztályban, milyen csoportban, milyen óraszámban és természetesen mely tanár vezetésével készült.

A DVD-én megtekinthető 14 óra témája a következő: A helyzeti energia, Anyagforgalom a membránon keresztül, Kémiai reakciók energiaváltozásai, Megújuló energiaforrások, Testrészekkel kapcsolatos kifejezések, A robotika alapjai, Negatív számok fogalma, modelljei, Törtek, Nemzeti parkjaink megismerése, Több erőhatás együttes eredménye, A romantika a festészetben, Kölcsey Ferenc és a Himnusz, A nagy földrajzi felfedezések, Four Families Picture Description, Robotok a tanítási órán. Szinte minden tantárgyhoz kapcsolódik egy-egy bemutatóóra. Az órák óravázlata nagyon pontosan rögzíti, hogy a diákoknak mit és honnan kell megnyitniuk, letölteniük, milyen feladatokkal kell dolgozniuk. Az óravázlatokat áttekintve láthatjuk, hogy az IKT mühely megalkotói nagy gondot fordítottak arra, hogy ne az interaktív tábla uralja az órát, hanem az egy olyan eszköz legyen, ami segíti a diákokat a megfelelő tudás elsajátításában. Az interaktív tábla tanórán történő használata motiválólag hathat a diákokra, szívesebben, nagyobb érdeklödéssel foglalkoznak egy-egy tananyaggal. Mindez azokból a riportokból is kiderül, amelyek azokkal a pedagógusokkal készültek, akik részt vettek az IKT mühely munkájában vagy az anyag tesztelésében. A riportok megtekinthetők az IKT mühely DVD-jén a riportok menüpont alatt. A riportok meghallgatása gyakorlati és szakmai szempontból is

\footnotetext{
${ }^{1}$ Széchenyi István Általános és Alapfokú Mủvészetoktatási Iskola, Bonyhád, Makói Általános Iskola, Alapfokú Mủvészetoktatási Intézmény és Logopédiai Intézet Almási Tagintézménye, Kós Károly Általános Iskola és Alapfokú Művészeti Iskola, Zsombó, Eszterházy Károly Főiskola Gyakorló Általános Iskola, Középiskola és Alapfokú Mủvészetoktatási Intézmény, Eger, valamint Ferenczi Sándor Egészségügyi Szakközépiskola Miskolc.
} 
fontos lehet. A riportalanyok, megfogalmazva észrevételeiket, ötleteiket, az IKT mühely munkájának számos részletéről részletes tájékoztatást adnak. Bemutatják az interaktív táblával támogatott óravezetés előnyeit és esetleges buktatóit is. A riportok nagymértékben hozzájárulhatnak ahhoz, hogy az interaktív táblát vagy más digitális eszközöket még nem használó pedagógusok is megérezzék, ezen eszközök használata, alkalmazása megtanulható, elsajátítható. Az IKT mühely óravázlataiból és az órák kisfilmjeiből is kiderül, hogy a munkában részt vevő pedagógusok a Sulinet portálon elérhető Celebrate tananyagból használnak részeket. Például az első kisfilmben (A helyzeti energia) az egyik animációs kísérlet (A leeső súly beveri a földbe a sárga színủ cölöpöt) való a Celebrate tananyagból. Természetesen az említett tananyagon kívül az órákon más internetes oldalakat is segítségül hívnak a pedagógusok. Mindezzel fejlesztik a diákok keresési és kiválasztási képességét. A pedagógus rávezetheti a diákokat arra, hogy egy-egy témához honnan és hogyan találhat megfelelö és megbízható anyagokat.

Az IKT mühely DVD-je könnyen használható, átlátható navigálási rendszerrel készült. A kezdőlapon 5 menüpont található: bevezetés, digitális kompetencia, megjegyzések, riportok, tanórák. A bevezetés és a digitális kompetencia menüpontok az anyag elméleti egységét tartalmazzák. A megjegyzések az órákkal kapcsolatos javaslatokat tartalmazzák. A riportok és a tanórák menüpontok, az anyag interaktív részét képezik.

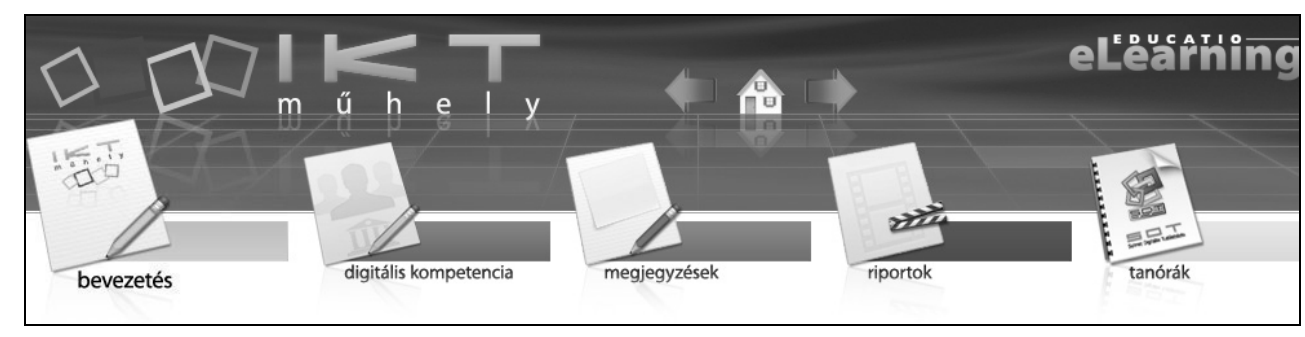

Ha a tanórák menüpontra kattintunk, megjelenik elöttünk a 14 óra listája. Ebböl a listából egy kattintással kiválaszthatjuk azt az órát, ami részletesebben érdekel bennünket. 


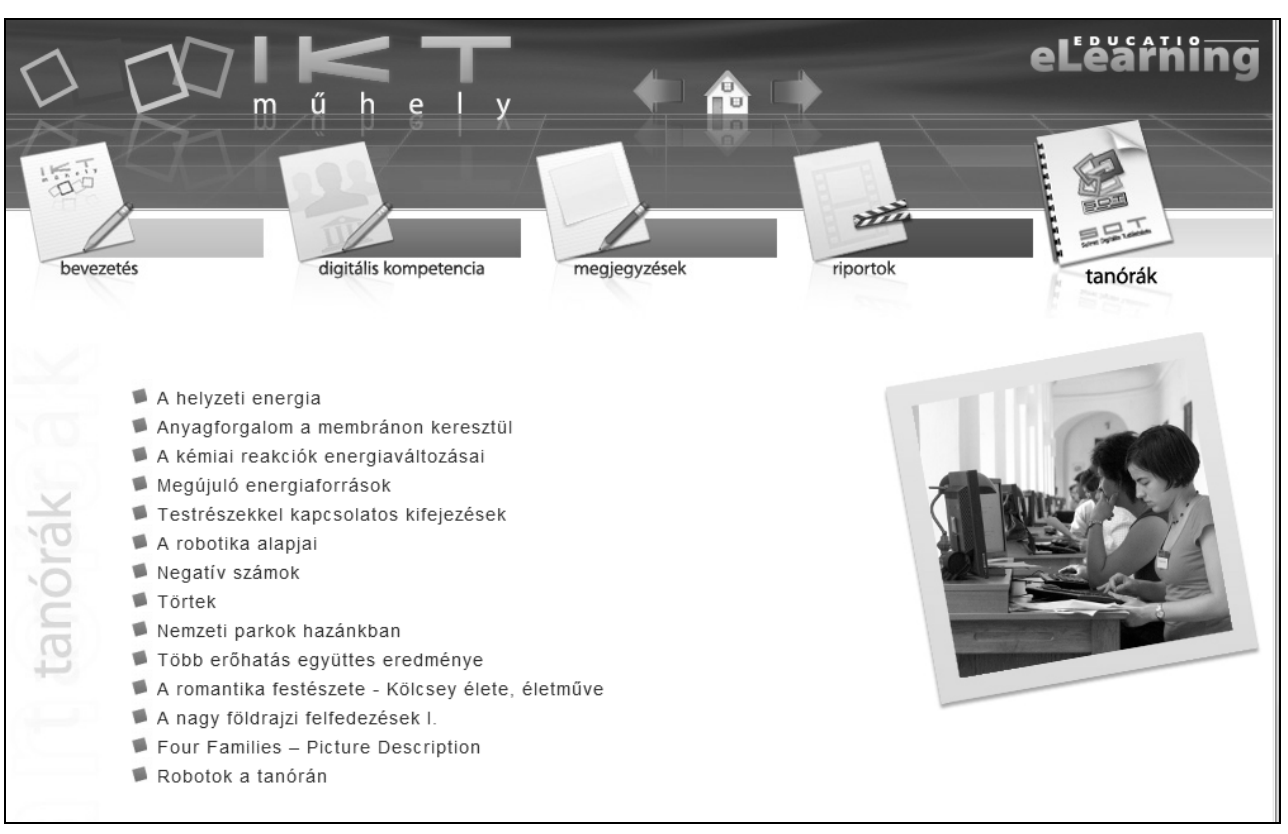

Rákattintva a megfelelő óra címére, egy újabb oldal jelenik meg előttünk. Valójában, mintha az IKT mühely könyvét tartanánk a kezünkben, csak digitális formában. Először a kiválasztott óra óravázlata nyílik meg elöttünk, majd újabb menüpontokon keresztül navigálva, megjeleníthetjük az óra technikai igényét, az órával kapcsolatos javaslatokat, az óra felvételét, valamint az órához tartozó SDT tananyagot.

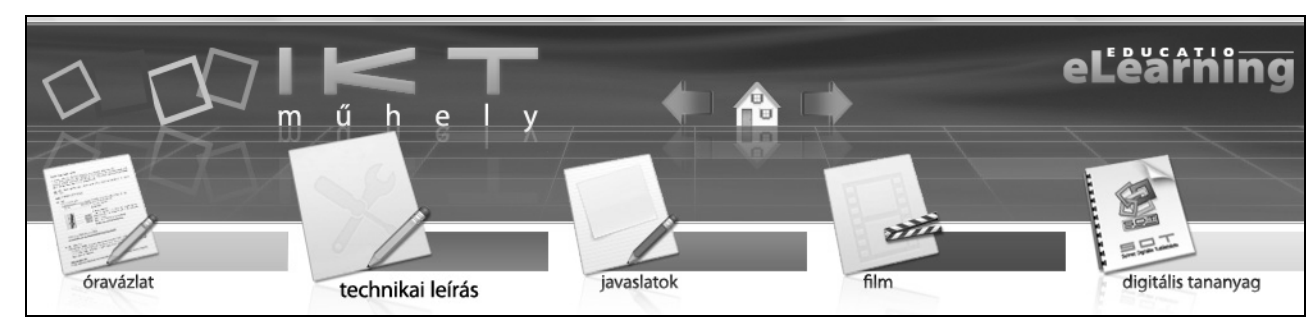

A film menüpontra kattintva indíthatjuk el a kiválasztott óra felvételét. A felvétel első részében elhangzik az óra célja is. A kisfilmek segítségével bővíthető a pedagógusok módszertani repertoárja, valamint látva az interaktív tábla segítségével megvalósított órát, nagyobb bátorsággal vághat neki a digitalizált világban még kevésbé jártas pedagógus is a munkának. A felvételek nemcsak az órát vezető pedagógust és a táblát mutatják, hanem a diákok arcát, mimikáját és ily módon non- 
verbális visszacsatolásaikat is. A felvételeken látható, hogy a diákok, korosztálytól függetlenül, nagy kedvvel, lelkesedéssel vesznek részt az interaktív táblával támogatott órákon. A tanórákon a hang, a kép és a szöveg együttesében zajlik a tanítási folyamat. A diákok ebben hármas rendszerben motiváltabbakká válhatnak, közelebbinek, elsajátíthatóbbnak érezhetik magukhoz a megtanulandó tananyagot.

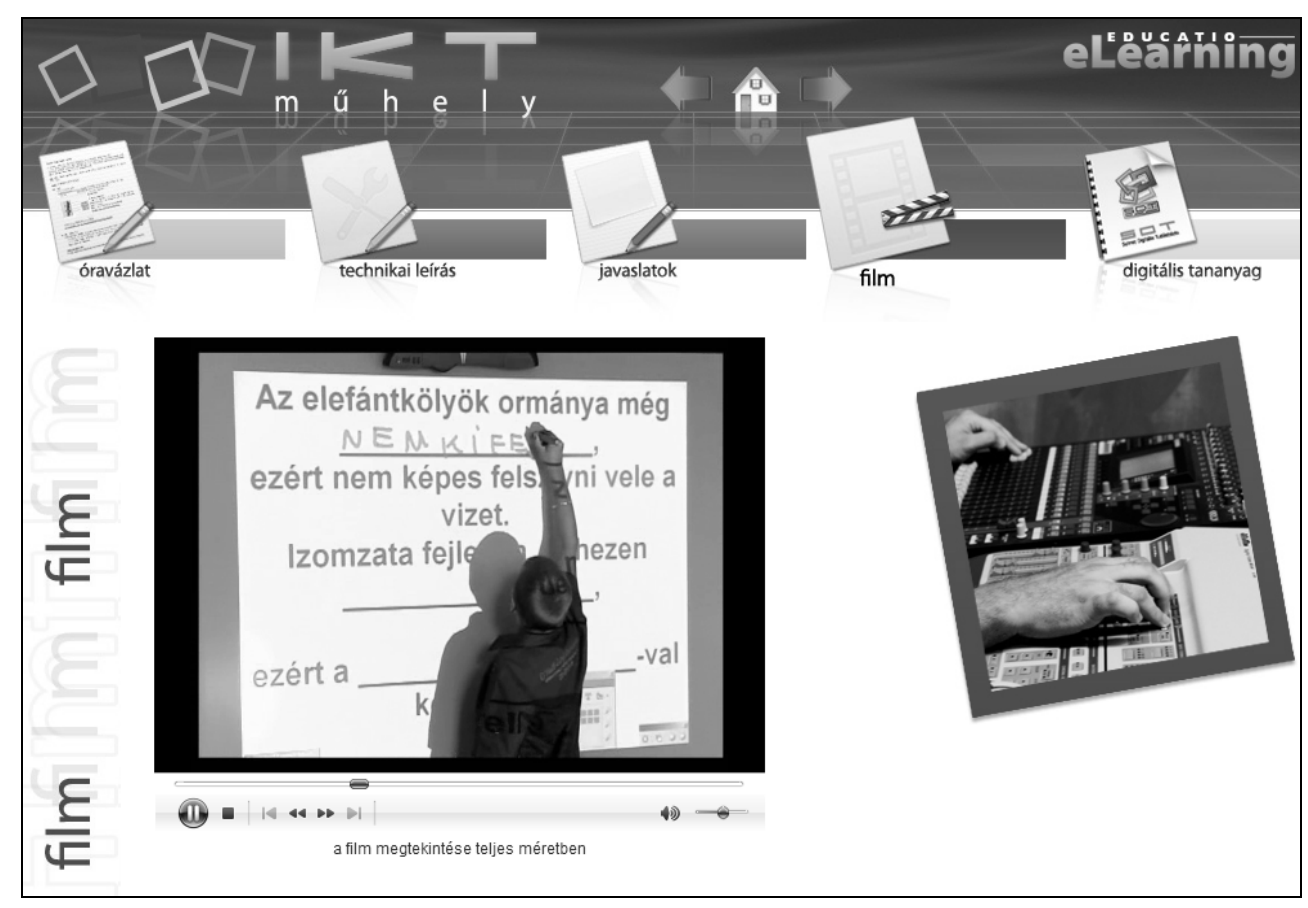

Az IKT mühely bevezetöjében és riportjaiban is többször elhangzik, hogy az interaktív táblát és más digitális eszközöket sem lehet öncélúan, helytelenül használni, mert a helytelen alkalmazás nagyon sok veszélyt rejthet magában. „Ezek hatékony eszközök, amelyeket nem megfelelö cél érdekében használva, átgondolatlanul alkalmazva ugyanúgy kárt okozhatunk, mint az az orvos, aki hatékony, korszerü gyógyszerek közül nem az adott betegség gyógyítására a legmegfelelöbbet választja ki, vagy túladagolja.,"2

A DVD-én meghallgatható riportokból az is kiderül, hogy a programban és a tesztelésben részt vevő pedagógusok úgy látják, az interaktív tábla segíthet a pedagógusoknak abban, hogy differenciált óraszervezést, kooperatív technikákat alkalmazzanak. A pedagógus együtt tud dolgozni a diákokkal, de fontos, hogy ne a ta-

\footnotetext{
${ }^{2}$ Részlet Falus Iván bevezetőjéből az IKT mühely című anyagban.
} 
nár uralja az órán a digitális táblát. Legyen lehetősége a diákoknak kipróbálni ezt az eszközt.

Az IKT mühely bemutat egy olyan lehetőséget is, ami eddig kevésbé volt ismert a pedagógusok elött. Ez az úgynevezett osztálytermi szavazórendszer. A szavazórendszer segítségével a pedagógus azonnali visszacsatolást kaphat egy óra végén a tananyag elsajátítására vonatkozóan. A pedagógus otthon előre megszerkesztheti a kérdéseket, amiket később elegendő módosítani, vagy egy ismétlő óránál egyszerüen elővenni.

Az IKT mühely anyaga előfeltételezi azt, hogy a pedagógus rendelkezik már egy bizonyos szintü előzetes digitális tudással. Képes kezelni az interaktív táblát, ismeri az SDT tananyagokat. Ha a pedagógus még nincs ezen tudás birtokában, akkor nagy segítséget jelenthet az Oktatási Minisztérium támogatásával és az Eszterházy Károly Főiskola Médiainformatikai Intézetének közremüködésével készült Interaktív Tábla címü DVD, ami az interaktív tábla használatát mutatja be a bekapcsolástól egészen a kész tanórákig és tananyagokig. Kimondottan módszertani anyagnak tekinthető ez a DVD, ami nemcsak az interaktív tábla használatának elméleti ismereteit tartalmazza, hanem óravázlatokat, a bemutató órák felvételeit és az órákhoz felhasznált multimédiás elemeket is. A kisfilmek elkészítésekor az Eszterházy Károly Főiskola Gyakorlóiskolájának hatodik és hetedik osztályai, valamint a kerecsendi Magyary Károly Általános Iskola és Zeneiskola hatodik és hetedik osztályai segítettek.

A DVD első fejezete „A digitális tábla üzembe helyezése” címet viseli. Ebben a fejezetben bemutatásra kerülnek a különféle interaktív táblák üzembe helyezésének lépései. Összesen hat féle digitális táblát mutat be a program: Clever Touch, Clever XI, e-Beam, Polyvision, Promethean, SMART. A kisfilmek a tábla üzembe helyezésének minden apró részletét bemutatják. A pedagógusok lépésről lépésre megtanulhatják a tábla összeszerelésének és üzembe helyezésének fontos lépéseit.

A DVD második fejezete „A digitális tábla az órán” címü. Ebben a fejezetben két kémia, két matematika, két történelem és két angol óra részleteit ismerheti meg a felhasználó. A felsorolt órák mindegyikéről kisfilm készült, amit végignézhet a felhasználó, miközben a képernyő jobb oldalán az óravázlatot (Tantárgy, Témakör, Téma, Óra típusa, Nevelési cél, Fejlesztési célok, Módszerek, Eszközök) tekintheti át. 


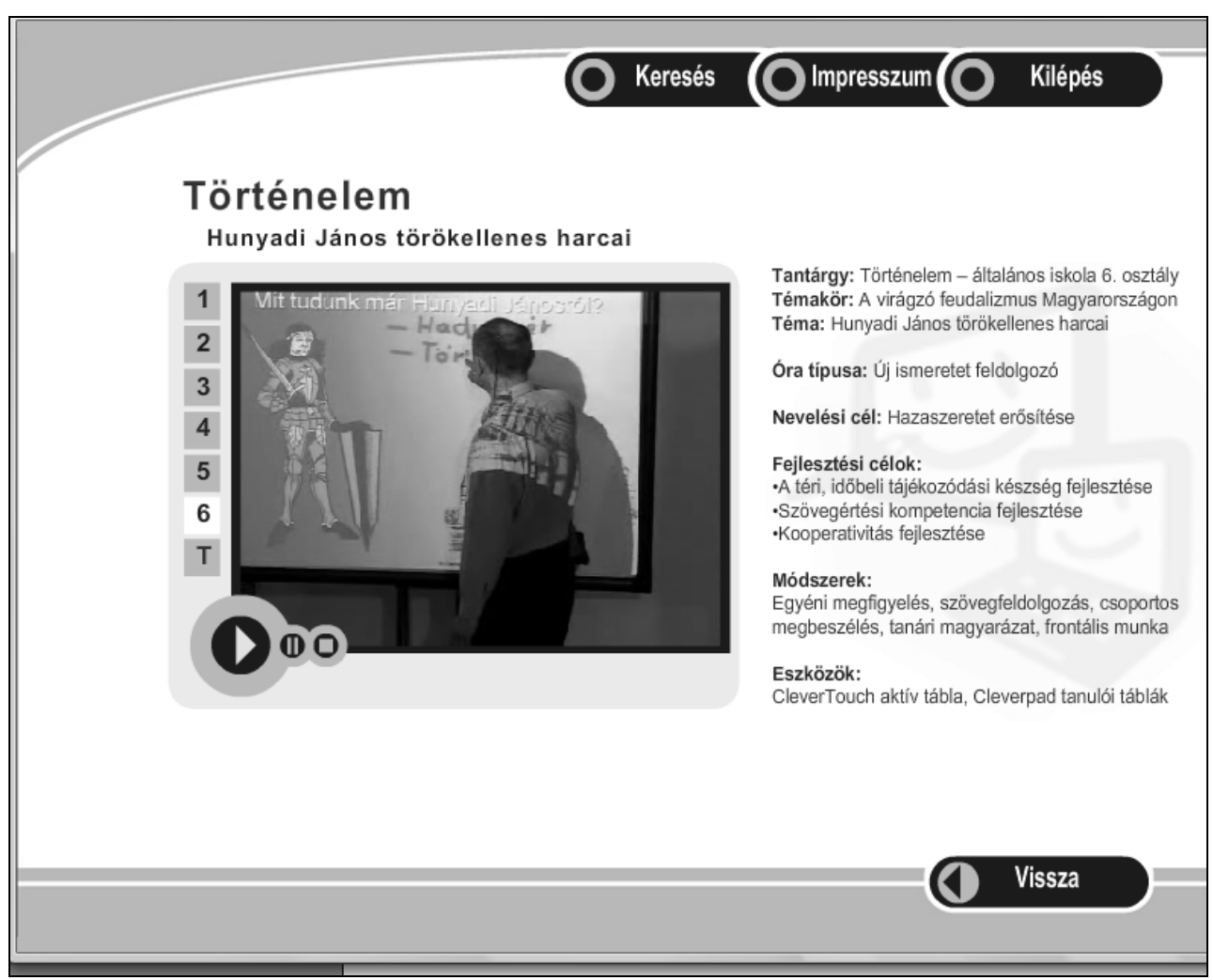

A bemutató órák egyikét színésztanárok vezetik, a másik bemutató órát pedig pedagógusok. A bemutató órák témája a következő: kémiából Az oldatok, valamint a Vas és a kén reakciója, matematikából A tengelyes tükrözés és a tengelyes tükrözés tulajdonságai, valamint $A$ tengelyes tükrözés és a tengelyesen tükrös síkidomok, angolból A futball és a futball története, valamint Városok, Országok, Földrészek, Hires helyek, nevezetességek, történelemböl Hunyadi János törökellenes harcai, valamint $A$ feudális nagybirtok, jobbágyi szolgáltatások.

A DVD harmadik fejezete a felhasznált tananyagelemeket és a médiaelemeket tartalmazza. Ebben a tananyagelem és médiaelem gyüjteményben a felhasználók megtalálhatnak minden olyan szövegfájlt, képfájlt, hangfájlt, amit a bemutató órákon a pedagógusok felhasználtak. Az óravázlatokat le is tölthetik a felhasználók.

A DVD szakmai értékét növeli az is, hogy egy Keresés funkciót is használhatnak a program alkalmazói. A keresés a DVD tartalmának egészében történhet. A keresett szót begépelve, a program kilistáz minden olyan helyet, ahol a keresett fogalom elöfordul. 


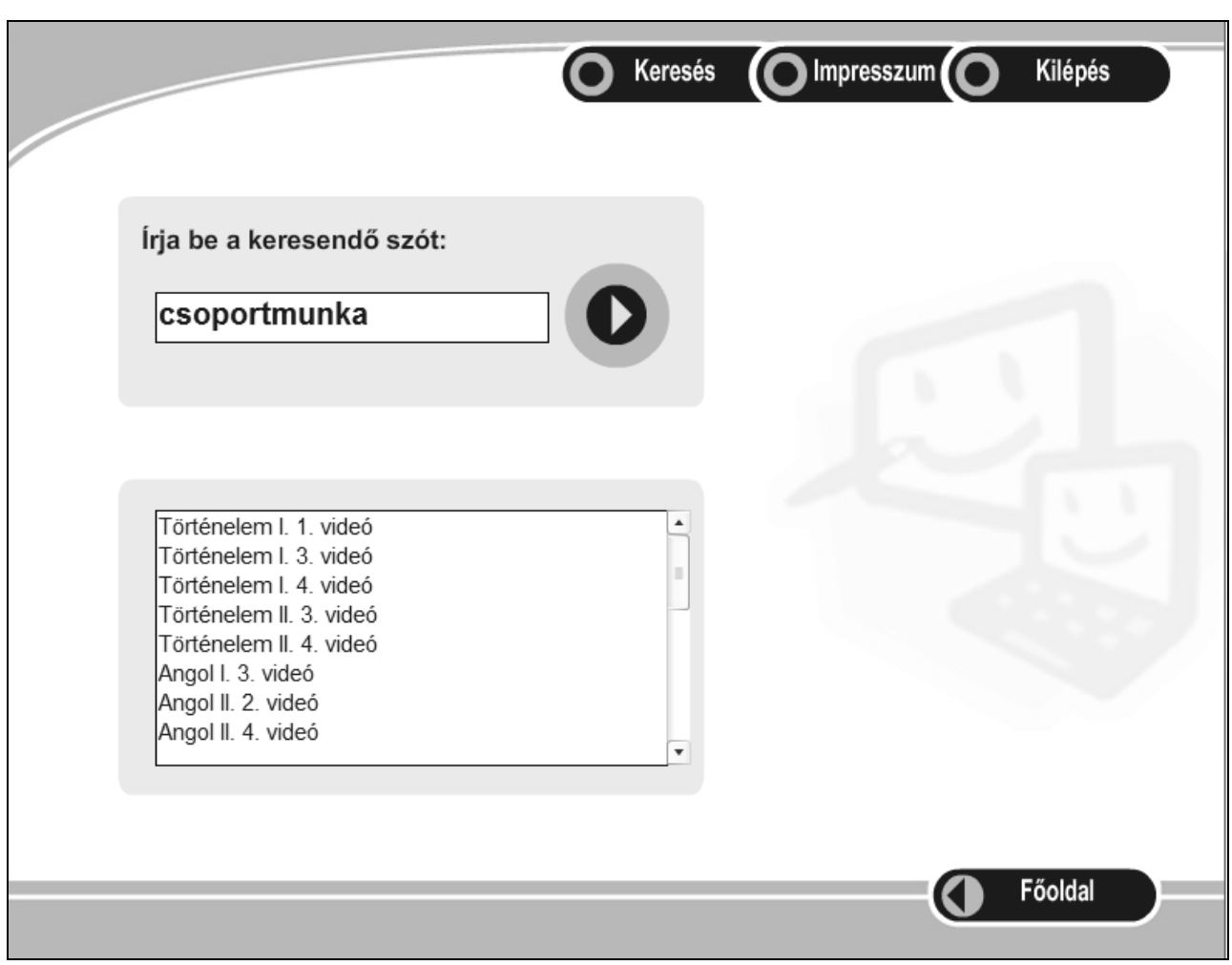

Látható, hogy a DVD több funkciót foglal magában. Egyrészt megtanít, akár autodidakta módon is arra, miként helyezzük üzembe az interaktív táblát, másrészt segítséget ad ahhoz, miként készítsünk óravázlatot, tananyagot az interaktív táblával támogatott tanórához.

Az Eszterházy Károly Főiskola mindkét interaktív DVD-je kiváló segítség a pedagógusok számára. Ahhoz azonban, hogy a pedagógusok célszerủen tudják alkalmazni ezeket az anyagokat saját tantárgyuknál, meg kell tanulniuk, miként tudják a meglévő anyagokat saját munkájukhoz, saját tanítványaikhoz formálni, alakítani, vagy egészen új tananyagokat készíteni. Mindez a tudás és képesség a pedagógusok digitális kompetenciájának részét kell, hogy képezze. A digitális kompetencia a nyolc kulcskompetencia egyike. Az egész életen át tartó tanuláshoz kapcsolódó egyik kompetencia. Éppen ezért egyetlen pedagógus sem engedheti meg magának, hogy figyelmen kívül hagyja a digitális kompetencia létezését arra az egyszerü indokra hivatkozva, hogy ö nem informatika szakos. Ma már nem lehet igaz Karl Kroeber gondolata: „A humán tudósnak, ha számitógép segitségét kívánja igénybe venni, egyetlen központi feladata van: hogy elmondja a gépkezelönek, mit szeretne elvégeztetni vele." (Kroeber, 1969, Helikon, 1969/3-4. sz. 393. o.) Napjainkban 
már magunknak kell alkalmassá válnunk arra, hogy adaptálva, vagy önállóan hozzunk létre tananyagokat az interaktív táblához, használjuk a különféle digitális eszközöket az órákon, de sosem öncélúan és mindig figyelve a megfelelő arányokra, mindig megtalálva a témához és az óra céljához leginkább passzoló módszert.

Az IKT mühely riportalanyai közül többen is megfogalmazták, hogy ha a hagyományos módszerektől nem is teljes mértékben, de a hagyományos tanárszereptôl teljesen el kell búcsúzni. Ma már nem lehet ugyanolyan attitüdökkel tanítani, mint évekkel ezelőtt. Sokan még mindig életidegennek tekintik az interaktív táblát, sokan pedig már évek óta használják. A pedagógusok bármely táboráról is legyen szó, az Eszterházy Károly Főiskola két DVD anyagát örömmel ajánlanám, mert a kezdeti lépésekben és a későbbi továbbfejlődésben, módszertani és szakmai repertoárbővítésben is kiváló segítséget nyújthat. A két DVD anyag igen jól használható gyakorlópedagógusok számára és most még az iskolapadban ülő, leendő tanárok számára is. ${ }^{3}$

IKT mühely. Educatio Kht. -eLearning Igazgatóság és Eszterházy Károly Föiskola, Budapest, 2008.

Forgó Sándor - Illés Tamás (szerk., 2006): Interaktív tábla. Eszterházy Károly Föiskola Médiainformatikai Intézet, Eger.

\footnotetext{
${ }^{3}$ A tanulmányban szereplö képek mindegyike az IKT mühely és az Interaktív Tábla címü digitális anyagokból való.
} 